\title{
ANALISIS PENGARUH TRANSPARANSI, AKUNTABILITAS DAN PEMANFAATAN SISTEM INFORMASI AKUNTANSI KEUANGAN DAERAH TERHADAP PENGELOLAAN APBD (Studi Persepsi Pengelola APBD SKPD Dinas Pemerintah Kota Padang)
}

\author{
Hari Sriwijayanti \\ Universitas Putra Indonesia YPTK Padang, Indonesia \\ hari0sriwijayanti@gmail.com
}

\begin{abstract}
ABSTRAK
Penelitian ini menguji pengaruh akuntabilitas, transparansi, dan pemanfaatan Sistem Informasi Akuntansi Keuangan Daerah (SIAKD) secara simultan dan parsial terhadap pengelolaan APBD. Sampel penelitian ini adalah pejabat Pengelolaan Keuangan Daerah yang melaksanakan pengelolaan APBD pada seluruh SKPD Dinas Pemerintah Kota Padang yang berjumlah 16 dinas. Teknik pengambilan sampel adalah dengan purposive sampling dengan jumlah responden 99 orang. Data dalam penelitian ini adalah data primer. Data dikumpulkan dengan menggunakan kuesioner yang dibagikan langsung kepada responden. Metode analisa yang digunakan adalah model regresi linear sederhana untuk menguji hipotesis secara parsial dengan uji $t$ dan regresi linear berganda untuk menguji hipotesis secara simultan dengan uji F. Hasil penelitian dan uji hipotesis menunjukkan bahwa persepsi pejabat pengelola APBD tentang transparansi, akuntabilitas, dan pemanfaatan SIAKD berpengaruh signifikan terhadap pengelolaan APBD baik secara parsial maupun simultan. Dari hasil penelitian diharapkan kepada pejabat pengelola APBD untuk lebih meningkatkan transparansi dan akuntabilitas dalam pengelolaan anggaran pada SKPD Dinas Pemerintah Kota Padang.
\end{abstract}

Keyword: Transparansi, Akuntabilitas, Pemanfaatan SIAKD, Pengelolaan APBD

\section{PENDAhuluan}

Good governance adalah tata kelola organisasi secara baik dengan prinsip keterbukaan, keadilan, dan dapat dipertanggungjawabkan dalam rangka mencapai tujuan organisasi (Syahkroza, 2003). Keberhasilan pengelolaan keuangan daerah mempunyai dampak langsung terhadap keberhasilan otonomi daerah dan sumbangan yang besar dalam upaya mewujudkan good governance (Darise, 2007). Anggaran Pendapatan dan Belanja Daerah (APBD) adalah pedoman bagi pemerintah daerah dalam melakukan pengelolaan keuangan daerah. Pengelolaan APBD yang baik menerapkan prinsip Value for Money (VfM). VFM merupakan prinsip pengelolaan organisasi sektor publik yang mendasar pada tiga elemen utama, yaitu: ekonomi, efisiensi, dan efektivitas. $V F M$ dapat tercapai apabila organisasi telah menggunakan biaya input paling kecil untuk mencapai output yang optimum dalam rangka mencapai tujuan organisasi (Mardiasmo, 2004). Agar prinsip VfM dapat diterapkan maka harus ditunjang juga dengan pelaksanaan transparansi, akuntabilitas serta pemanfaatan Sistem Informasi Akuntansi Keuangan Daerah (SIAKD) dalam pengelolaan APBD, sehingga pemanfaatan APBD yang hemat, adil, merata dan sesuai dengan kebutuhan masyarakat dapat tercapai.

Transparansi adalah keterbukaan atas semua tindakan dan kebijakan yang diambil oleh pemerintah. Transparansi pengelolaan keuangan daerah pada akhirnya akan menciptakan horizontal accountability antara 
pemerintah daerah dengan masyarakatnya sehingga tercipta pemerintahan daerah yang bersih, efektif, efisien, akuntabel, dan responsif terhadap aspirasi dan kepentingan masyarakat (Sumarsono, 2009). Transparansi APBD merupakan salah satu aspek penting dalam menjalankan program pemerintah daerah, dan secara umum dalam usaha meningkatkan kesejahteraan masyarakat daerah tersebut. Sedangkan akuntabilitas adalah kewajiban pihak pemegang amanah (agent) untuk memberikan pertanggungjawaban, menyajikan, melaporkan, dan mengungkapkan segala aktivitas dan kegiatan yang menjadi tanggung jawabnya kepada pihak pemberi amanah (principal) yang memiliki hak dan kewenangan untuk meminta pertanggungjawaban tersebut (Halim, 2006). Jadi dalam hal ini pemerintah bisa disebut sebagai pemegang amanah (agent) yang akan mengelola dana yang sudah disumbangkan oleh masyarakat, dan masyarakat sebagai pemberi amanah (principal) mempunyai hak untuk mengetahui bagaimana pertanggungjawaban dana tersebut.

Reformasi di bidang keuangan menuntut peningkatan kinerja tata kelola keuangan daerah yang akuntabel dan transparan sebagai salah satu indikator ketercapaian good governance, salah satu kriterianya adalah ketepatan dan keakuratan pengelolaan keuangan pemerintah daerah melalui pemanfaatan SIAKD. SIAKD dapat menghasilkan laporan keuangan yang relevan, handal, dan dapat dipercaya (Mardiasmo 2004). Dengan dikeluarkannya Peraturan Pemerintah No. 65 Tahun 2010 tentang Sistem Informasi Keuangan Daerah (SIKD) disebutkan bahwa untuk menindaklanjuti terselenggaranya proses pembangunan yang sejalan dengan prinsip tata kelola pemerintah yang baik (good governance), Pemerintah Pusat dan Pemerintah Daerah berkewajiban untuk mengembangkan dan memanfaatkan kemajuan teknologi informasi untuk meningkatkan kemampuan pengelolaan keuangan, dan menyalurkan informasi keuangan kepada publik sebagai wujud transparansi dan akuntabilitas atas kegiatan yang dilakukan pemerintah.

Persoalan utama pengelolaan anggaran pada Pemerintah Kota Padang adalah: Pertama, masih minimnya penyerapan APBD pada beberapa SKPD Pemerintah Kota Padang (Harian Padang Ekspres, diakses 28 April 2015), yang disebabkan oleh adanya ketakutan dari pejabat pengelola anggaran untuk menggunakan anggaran dan masih adanya proyek dalam proses tender. Kedua, karena penyerapan anggaran minim, kegiatan dan program berjalan lambat sehingga beberapa SKPD serapan anggarannya tidak mencapai target. Berdasarkan data di BPKD (Badan Pengelolaan Keuangan Daerah) Padang, ada beberapa SKPD yang serapan anggarannya tidak mencapai target. Seperti, Dinas Perindagtamben (13,33\%), RSUD Rasidin (25,51\%), Bappeda (30,97\%), Sekretariat Daerah (35,34\%), Dinas Pekerjaan Umum (37,88\%), BPMP2T (38,64\%), Dinas TRTB dan Perumahan (38,72\%), dan Dinsosnaker (42,06\%) (PosMetro Padang, September 2015). Persoalan ketiga, adalah timbulnya kesan kebiasaan menghabiskan anggaran diakhir tahun, ada kesan dikejar waktu untuk memakai anggaran, sehingga hasilnya juga tidak maksimal, karena tujuan utama bukan lagi membangun perekonomian melainkan mempergunakan seluruh anggaran yang biasanya di akhir tahun masih tersisa dalam jumlah besar.

Berbeda dengan penelitian sebelumnya, pada penelitian ini peneliti mengkombinasikan variabel transparansi, akuntabilitas, dan pemanfaatan SIAKD sebagai variabel independen. Sesuai dengan uraian yang sudah dijelaskan diatas, jelaslah bahwa pemanfaatan SIAKD perlu diperhitungkan dalam pengelolaan APBD. Seperti penelitian Bakar (2010) menyimpulkan bahwa secara simultan pemanfaatan SIAKD berpengaruh signifikan terhadap kualitas laporan keuangan Pemerintah Daerah. Sedangkan secara parsial tidak berpengaruh signifikan. Penelitian yang dilakukan oleh Diani (2014) menyimpulkan bahwa pemanfaatan SIAKD tidak berpengaruh signifikan terhadap kualitas laporan keuangan Pemerintah. Ridhawati (2014) menyimpulkan bahwa pemanfaatan teknologi informasi tidak berpengaruh signifikan terhadap keterandalan laporan Pemerintah Daerah, akan tetapi pemanfaatan teknologi informasi berpengaruh sigifikan terhadap ketepatan waktu laporan keuangan.

\section{TINJAUAN PUSTAKA}

\subsection{Teori Keagenan (Agency Theory)}


Menurut Anthony dan Govindarajan (2005), teori agensi adalah hubungan atau kontrak antara principal dan agent. Prinsip utama teori ini menyatakan adanya hubungan kerja antara pihak yang memberi wewenang (prinsipal) yaitu investor dengan pihak yang menerima wewenang (agensi) yaitu manajer, dalam bentuk kontrak kerja sama.

Halim dan Abdullah (2006) menyatakan bahwa masalah keagenan di pemerintahan daerah belangsung secara terus menerus dan saling terkait pada semua tingkatan. Peraturan perundangan sendiri adalah salah satu bentuk kontrak yang bersifat semi-given, yakni dibentuk berdasarkan konstitusi oleh mekanisme politik pada level pemerintahan yang lebih tinggi. Oleh karena itu, kepala SKPD adalah agen bagi kepala daerah dan kepala daerah adalah agen bagi DPRD dan masyarakat.

\subsection{Keuangan Daerah}

Halim (2002) mengartikan keuangan daerah sebagai semua hak dan kewajiban yang dapat dinilai dengan uang, demikian pula segala sesuatu baik berupa uang maupun barang yang dapat dijadikan kekayaan daerah sepanjang itu belum dimiliki/dikuasai oleh Negara atau daerah yang lebih tinggi serta pihak-pihak lain sesuai ketentuan/peraturan undang-undang yang berlaku. Menurut Peraturan Menteri Dalam Negeri No. 13 Tahun 2006 yang sudah diperbaharui dengan Permendagri No. 21 Tahun 2011 tentang pedoman pengelolaan keuangan daerah, merupakan keseluruhan kegiatan yang meliputi perencanaan, pelaksanaan, penatausahaan, pelaporan, pertanggungjawaban, dan pengawasan keuangan daerah. Dalam konteks ini pengelolaan keuangan daerah difokuskan kepada pengelolaan.

\subsection{Anggaran Pendapatan dan Belanja Daerah (APBD)}

Menurut Bastian (2006) anggaran pendapatan dan belanja daerah, yang selanjutnya disebut APBD, adalah rencana keuangan tahunan pemerintah daerah yang ditetapkan dengan peraturan daerah. APBD merupakan dasar pengelolaan keuangan daerah dalam masa 1 (satu) tahun anggaran terhitung mulai 1 Januari sampai dengan tanggal 31 Desember. APBD adalah rencana keuangan tahunan daerah yang dibahas dan disetujui bersama oleh Pemerintah Daerah dan DPRD, dan ditetapkan dengan Peraturan Daerah (Permendagri No.13 Tahun 2006 yang telah diperbaharui dengan Permendagri No. 59 Tahun 2007). Pengetian APBD dalam konteks UU Keuangan Negara pasal 1 ayat (8) adalah suatu rencana keuangan tahunan daerah yang disetujui oleh dewan perwakilan rakyat daerah (DPRD).

\subsection{Good Governance (Kepemerintahan yang Baik)}

Konsep "governance" bukanlah sesuatu hal yang baru. Istilah "government" dan "governance" seringkali dianggap memiliki kesamaan arti yaitu cara menerapkan otoritas dalam suatu organisasi, lembaga atau negara. Definisi government atau pemerintah adalah lebih mengacu kepada entitas yang menyelenggarakan kekuasaan pemerintah dalam suatu negara. Sedangkan governance seringkali diartikan sebagai proses pengambilan keputusan dan proses dimana keputusan diimplementasikan atau tidak diimplementasikan (World Bank, 1992).

\subsection{Transparansi}

Transparansi dapat dikatakan sebagai suatu aturan yang membentuk dan mengupayakan pelaporan, kebijakan-kebijkan yang relevan, informasi lebih mudah diakses dan kredibel (James e. dan Lowry. 2010). Transparansi bermakna tersedianya informasi yang cukup, akurat dan tepat waktu tentang kebijakan publik, dan proses pembentukannya. Informasi adalah suatu kebutuhan penting masyarakat untuk berpartisipasi dalam pengelolaan daerah. Dengan ketersediaan informasi, masyarakat dapat ikut sekaligus mengawasi sehingga 
kebijakan publik yang muncul bisa memberikan hasil yang optimal bagi masyarakat, serta mencegah terjadinya kecurangan dan manipulasi yang hanya akan menguntungkan salah satu kelompok masyarakat saja secara tidak proporsional.

\subsection{Akuntabilitas}

Instrumen utama dari akuntabilitas keuangan adalah anggaran pemerintah, data yang secara periodik dipublikasikan, laporan tahunan dan hasil investigasi dan laporan umum lainnya yang disiapkan oleh agen yang independen. Anggaran tahunan secara khusus mempunyai otoritas legal untuk pengeluaran dana publik, sehingga proses penganggaran secara keseluruhan menjadi relevan untuk manajemen fiskal dan untuk melaksanakan akuntabilitas keuangan dan pengendalian pada berbagai tingkat operasi (Shende et al, 2004). Akuntabilitas adalah kewajiban pihak pemegang amanah (agent) untuk memberikan pertanggungjawaban, menyajikan, melaporkan, dan mengungkapkan segala aktivitas dan kegiatan yang menjadi tanggung jawabnya kepada pihak pemberi amanah (principal) yang memiliki hak dan kewenangan untuk meminta pertanggungjawaban tersebut (Halim, 2006).

\subsection{Sistem Informasi Akuntansi Keuangan Daerah}

Peraturan Pemerintah Republik Indonesia Nomor 65 Tahun 2010 tentang SIKD menyebutkan SIKD adalah suatu sistem yang mendokumentasikan, mengadministrasikan, serta mengolah data pengelolaan keuangan daerah dan data terkait lainnya menjadi informasi yang disajikan kepada masyarakat dan sebagai bahan pengambilan keputusan dalam rangka perencanaan, pelaksanaan, dan pelaporan pertanggungjawaban pemerintah daerah. Dengan demikian SIAKD merupakan sebuah sistem informasi yang digunakan untuk menunjang pengelolaan keuangan daerah secara terintegrasi, meliputi pengaanggaran, penatausahaan, akuntansi dan pelaporannya. Menurut Mardiasmo (2004), SIAKD dapat menghasilkan laporan keuangan yang relevan, handal, dan dapat dipercaya.

\subsection{Value for Money (VFM)}

Indikasi keberhasilan otonomi daerah dan desentralisasi adalah terjadinya peningkatan pelayanan dan kesejahteraan masyarakat (social welfare) yang semakin baik, kehidupan demokrasi yang semakin maju, keadilan, permerataan, serta adanya hubungan yang serasi antara pusat dan daerah serta antar daerah. Keadaan tersebut hanya akan tercapai apabila lembaga sektor public dikelola dengan memperhatikan konsep value for money (Mardiasmo, 2004). VfM merupakan konsep pengelolaan organisasi sektor publik yang mendasarkan pada tiga jenis elemen yaitu: ekonomi, efisiensi, dan efektivitas (Renyowijoyo, 2008).

\section{METODA PENELITIAN \\ 3.1 Jenis dan Desain Penelitian}

Berdasarkan karakteristik dari penelitian ini, maka jenis penelitian ini merupakan penelitian kausal dengan metode kuantitatif dengan pendekatan deskriptif. Peneliti menggunakan penelitian ini untuk memberikan bukti empiris dari analisis pengaruh transparansi, akuntabilitas dan pemanfaatan SIAKD terhadap pengelolaan APBD.

\subsection{Objek Penelitian}

Objek penelitian dari penelitian ini adalah seluruh SKPD Dinas Pemerintah Kota Padang yang berjumlah 16 Dinas. 


\subsection{Populasi dan Sampel Penelitian}

Populasi dalam penelitian ini adalah seluruh pejabat yang melaksanakan pengelolaan keuangan daerah. Sesuai dengan Permendagri No. 13 Tahun 2006 yang sudah diperbaharui dengan Permendagri No. 21 Tahun 2011 tentang pedoman pengelolaan keuangan daerah, menyatakan bahwa Pejabat Pengelola Keuangan Daerah adalah pejabat selaku pengguna anggaran/pengguna barang yang mempunyai tugas untuk melaksanakan pengelolaan APBD yaitu: (1) Kepala SKPD selaku Pejabat Pengguna Anggaran/Pengguna Barang, (2) Pejabat Kuasa Pengguna Anggaran/Kuasa Pengguna Barang, (3) Pejabat Pelaksana Teknis Kegiatan SKPD, (4) Pejabat Penatausahaan Keuangan SKPD, dan (5) Bendahara Penerimaan dan Pengeluaran Kas.

Berangkat dari rincian Pejabat Pengelola Keuangan Daerah tersebut, maka yang menjadi populasi dalam penelitian ini adalah seluruh pejabat yang bertugas melaksanakan pengelolaan APBD pada seluruh Dinas Pemerintah Kota Padang yang berjumlah 131 orang. Adapun teknik pengambilan sampel dalam penelitian ini dilakukan dengan purposive sampling. Purposive sampling adalah teknik pengambilan sampel dengan pertimbangan atau kriteria tertentu yakni sumber data dianggap paling tahu tentang apa yang diharapkan dari penelitian (Sugiyono, 2012). Kriteria sampel dalam penelitian ini adalah: pejabat yang meduduki posisi sebagai pelaksana pengelolaan APBD pada seluruh Dinas Pemerintah Kota Padang dan pejabat pengelola yang bersedia merespon kuisioner yang diberikan. Jumlah sampel dalam penelitian ini adalah sebanyak 99 orang. Untuk menentukan jumlah sampel, digunakan rumus Slovin.

\subsection{Teknik Pengumpulan Data}

Teknik pengumpulan data adalah Field research (Penelitian Lapangan). Jenis data yang digunakan dalam penelitian ini adalah data primer. Pengumpulan data primer dalam penelitian ini menggunakan instrument penelitian dalam bentuk angket atau kuisioner.

\subsection{Variabel dan Pengukuran Operasional Variabel 3.5.1 Pengelolaan APBD (Y)}

Dalam penelitian ini yang menjadi variabel dependen adalah pengelolaan APBD. Pengelolaan APBD meliputi kegiatan perencanaan, pelaksanaan, penatausahaan, pelaporan, pertanggungjawaban, dan pengawasan. Menurut Darise (2007) APBD merupakan instrumen yang akan menjamin terciptanya disiplin dalam proses pengambilan keputusan terkait dengan kebijakan pendapatan maupun belanja daerah. Pengukuran dilakukan dengan menggunakan skala likert 1-5 poin. Adapun indikator yang digunakan untuk mengukur pengelolaan APBD adalah dengan menerapkan prinsip value for money yaitu : (1) Ekonomis, merupakan ukuran penggunaan dana masyarakat sesuai kebutuhan sesungguhnya. (2) Efisien, merupakan ukuran penggunaan dana masyarakat yang dapat menghasilkan output maksimal. (3) Efektifitas, merupakan ukuran seberapa jauh tingkat output, kebijakan dan prosedur dapat mencapai kepentingan publik.

\subsubsection{Transparansi $\left(\mathrm{X}_{1}\right)$}


Transparansi merupakan variabel independen pertama dalam penelitian ini. Transparansi dibangun atas dasar arus informasi yang bebas, seluruh proses pemerintahan, lembaga-lembaga dan informasi perlu dapat diakses oleh pihak-pihak yang berkepentingan. Untuk mengukur variabel transparansi digunakan indikator yang mengacu pada penelitian yang dilakukan oleh Siregar (2011) dan Suparno (2012), yaitu: (1) Terdapat pengumuman kebijakan anggaran, (2) Tersedia dokumen anggaran dan mudah diakses, (3) Tersedia laporan pertanggungjwaban yang tepat waktu, (4) Terakomodasinya suara/usulan rakyat, dan (5) Terdapat sistem pemberian informasi kepada publik.

\subsubsection{Akuntabilitas $\left(\mathrm{X}_{2}\right)$}

Akuntabilitas adalah variabel independen kedua dalam penelitian ini. Akuntabilitas adalah kewajiban pemerintah daerah untuk memberikan pertanggungjawaban, menyajikan, melaporkan, dan mengungkapkan segala aktifitas yang terkait dengan penerimaan dan penggunaan uang publik kepada pihak yang memiliki hak dan kewenangan untuk meminta pertanggungjawaban tersebut. Untuk mengukur variabel auntabilitas digunakan indikator yang mengacu pada penelitian yang dilakukan oleh Siregar (2011) dan Suparno (2012). Adapun indikator yang digunakan untuk mengukur akuntabilitas adalah adalah: (1) Menyajikan informasi penyelengaraan secara terbuka, cepat, tepat kepada masyarakat, (2) Memberikan pelayanan yang memuaskan bagi publik, (3) Partisipasi publik, (4) Menjelaskan dan mempertanggungjawabkan setiap kebijakan publik, dan (5) Adanya sarana bagi publik untuk menilai kinerja pemerintah.

\subsubsection{Pemanfaatan SIAKD $\left(\mathbf{X}_{3}\right)$}

Pemanfaatan SIAKD adalah variabel independen ketiga dalam penelitian ini. Pemanfaatan SIAKD akan sangat membantu mempercepat proses pengolahan data transaksi dan penyajian laporan keuangan pemerintah sehingga laporan keuangan tersebut tidak kehilangan nilai informasi. Dengan demikian, dimanfaatkannya sistem informasi akuntansi keuangan daerah dalam pengelolaan APBD, maka pengelolaan, dan akses terhadap informasi keuangan daerah dapat dilakukan lebih cepat dan akurat. Untuk mengukur variabel transparansi digunakan indikator yang mengacu pada penelitian yang dilakukan oleh Yuliani, dkk (2010), Ridhawati (2014), dan Diani (2014).

Indikator yang digunakan untuk mengukur pemanfaatan SIAKD adalah adalah: (1) Sistem informasi akuntansi memenuhi prinsip kecepatan dan mampu menyediakan informasi secara tepat waktu, (2) Sistem informasi akuntansi dilengkapi dengan pemanfaatkan teknologi informasi dan internet, (3) Penggunaan Sistem informasi akuntansi dapat meningkatkan efisiensi proses sehingga bisa memenuhi prinsip keekonomisan, (4) Sistem Informasi Akuntansi dapat dipahami dan mudah digunakan oleh setiap pengguna yang berkepentingan, dan (5) Sistem Informasi Akuntansi menghasilkan informasi yang lebih berkualitas, bernilai dan sesuai dengan kebutuhan pengguna informasi.

\section{HASIL DAN PEMBAHASAN \\ 4.1 Uji Hipotesis \\ 4.1.1 Analisis Regresi Linear Sederhana}

Untuk menguji pengaruh variabel independen terhadap variabel dependen secara parsial, dilakukan dengan analisis regresi sederhana dengan uji t dengan tingkat signifikansi $(\alpha=0,05)$. Dengan ketentuan, jika 
$t_{\text {hitung }}>t_{\text {tabel }} \mathrm{H}_{0}$ ditolak dan $\mathrm{H}_{1}$ diterima atau dengan kata lain hipotesis yang diajukan dapat diterima (terdapat pengaruh), begitu juga sebaliknya.

\section{Pengujian Hipotesis 1}

Hipotesis yang akan diuji adalah untuk mengetahui ada tidaknya pengaruh dari variabel transparansi $\left(\mathrm{X}_{1}\right)$ terhadap pengelolaan APBD $(\mathrm{Y})$.

Tabel 1

Ringkasan Hasil Analisis Regresi Sederhana Hipotesis 1

\begin{tabular}{|c|c|c|c|c|c|c|c|c|}
\hline \multicolumn{9}{|c|}{ Dependent Variable: Pengelolaan APBD (Y) } \\
\hline \multicolumn{5}{|c|}{ Variabel Independen } & & B & $\mathbf{T}$ & Sig \\
\hline \multicolumn{5}{|l|}{ (Constant) } & & 24.916 & 7.474 & 0.000 \\
\hline \multicolumn{5}{|c|}{ Transparansi $\left(\mathrm{X}_{1}\right)$} & & 0.397 & 4.819 & 0.000 \\
\hline $\mathrm{R}^{2}$ & $=$ & 0.219 & \multicolumn{6}{|c|}{ Adjusted $\mathrm{R}^{2}=0.209$} \\
\hline $\mathrm{R}$ & $=$ & 0.468 & \multicolumn{6}{|c|}{ Sig $=0.000$} \\
\hline $\mathrm{t}$ tabel & $=$ & 1.990 & & & & & & \\
\hline \multicolumn{9}{|c|}{ Keterangan: *Signifikan pada taraf kepercayaan $95 \%$} \\
\hline \multicolumn{9}{|c|}{ Persamaan $=\quad \mathrm{Y}=\alpha+\mathrm{b}_{1} \mathrm{X}_{1}+\mathrm{e}$} \\
\hline Regresinya & & $=$ & $\mathrm{Y}=24, \mathrm{C}$ & $0,397 \mathrm{X}_{1}+\mathrm{e}$ & & & & \\
\hline
\end{tabular}

Sumber : data primer diolah (2015)

Nilai R (koefisien korelasi) $=0,468$ yang berarti terjadi hubungan yang sedang antara transparansi dengan pengelolaan APBD sebesar 46,8\%. Untuk melihat kemampuan variabel independen transparansi $\left(\mathrm{X}_{1}\right)$ memprediksi variabel dependen pengelolaan APBD $(\mathrm{Y})$, dengan melihat nilaideterminasi $\left(\mathrm{R}^{2}\right)$ yaitu sebesar 0,219 berarti 21,9\% pengelolaan APBD dapat dijelaskan oleh variabel independen transparansi. Sedangkan sisanya dijelaskan oleh sebab-sebab yang lain diluar model. Secara parsial variabel transparansi mempunyai pengaruh signifikan terhadap pengelolaan APBD dengan nilai t-hitung 4,819>t-tabel 1,990 dengan probabilita sig $=0,000<\alpha 0,05$. Maka dapat disimpulkan bahwa $\mathrm{H}_{\mathrm{a} 1}$ diterima dan $\mathrm{H}_{01}$ ditolak.

\section{Pengujian Hipotesis 2}

Hipotesis yang akan diuji adalah untuk mengetahui ada tidaknya pengaruh dari variabel akuntabilitas $\left(\mathrm{X}_{2}\right)$ terhadap pengelolaan APBD $(\mathrm{Y})$.

Tabel 2

Ringkasan Hasil Analisis Regresi Sederhana Hipotesis 2

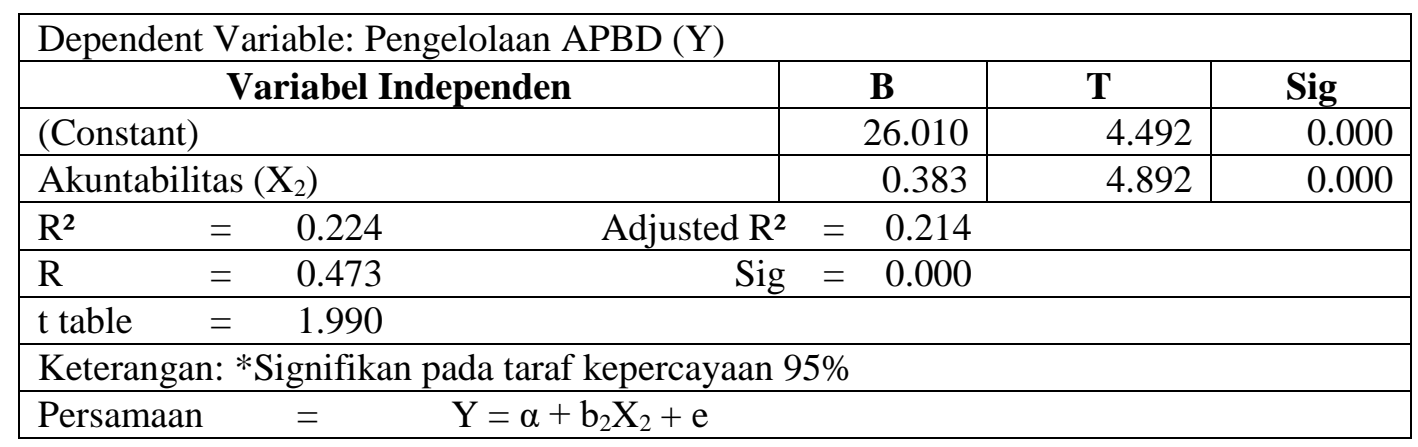




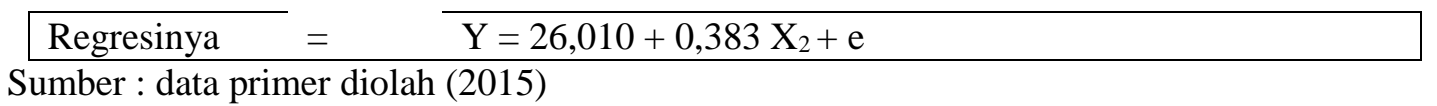

Nilai $\mathrm{R}=0,473$ yang berarti terjadi hubungan yang sedang antara akuntabilitas dengan pengelolaan APBD sebesar 47,3\%. Sedangkan nilai analisis determinasi $\left(\mathrm{R}^{2}\right)$ sebesar 0, 224, hal ini berarti $22,4 \%$ Pengelolaan APBD dapat dijelaskan oleh variabel independen akuntabilitas. Sedangkan sisanya dijelaskan oleh sebab-sebab yang lain diluar model yang mempengaruhi pengelolaan APBD. Secara parsial variabel akuntabilitas mempunyai pengaruh signifikan terhadap pengelolaan APBD. Dengan nilai t-hitung 4,892 > ttabel 1,990 dengan nilai probabilita $\operatorname{sig}=0,000<\alpha 0,05$. Maka dapat disimpulkan bahwa $\mathrm{H}_{\mathrm{a} 1}$ diterima dan $\mathrm{H}_{01}$ ditolak.

\section{Pengujian Hipotesis 3}

Hipotesis yang akan diuji adalah untuk mengetahui ada tidaknya pengaruh dari variabel pemanfaatan SIAKD $\left(\mathrm{X}_{3}\right)$ terhadap pengelolaan APBD (Y).

Tabel 3

Ringkasan Hasil Analisis Regresi Sederhana Hipotesis 3

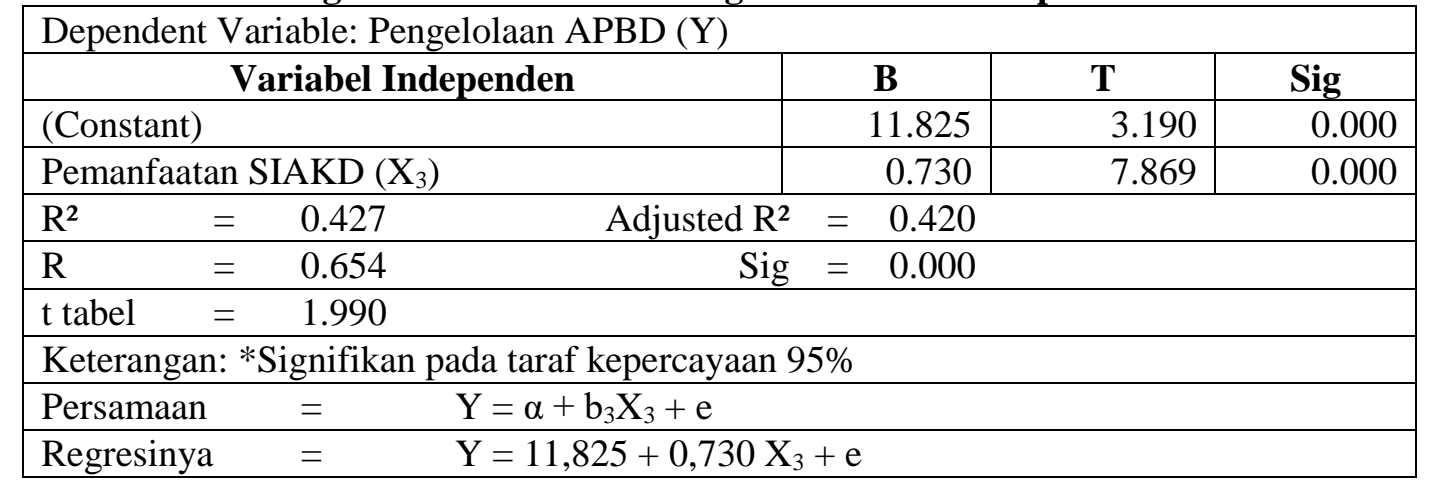

Sumber : data primer diolah (2015)

Nilai $R=0,654$ yang berarti terjadi hubungan yang kuat antara pemanfaatan SIAKD dengan pengelolaan APBD sebesar 65,4\%. Sedangkan dengan nilai analisa determinasi $\left(\mathrm{R}^{2}\right)$ sebesar 0, 427, hal ini berarti 42,7\%, pengelolaan APBD dapat dijelaskan oleh variabel independen pemanfaatan SIAKD. Sedangkan sisanya dijelaskan oleh sebab-sebab yang lain diluar model. Secara parsial variabel pemanfaatan SIAKD mempunyai pengaruh signifikan terhadap pengelolaan APBD. Dengan nilai t-hitung 7,869 > t-tabel 1,990 dengan nilai probabilita sig $=0,000<0,05$. Maka dapat disimpulkan bahwa $\mathrm{H}_{\mathrm{a} 1}$ diterima dan $\mathrm{H}_{01}$ ditolak.

\subsubsection{Analisis Regresi Berganda}

Untuk menguji pengaruh variabel independen terhadap variabel dependen secara bersama-sama (simultan), maka dilakukan dengan analisis regresi berganda dengan uji $\mathrm{F}$.

\section{Pengujian Hipotesis 4}

Hipotesis yang akan diuji adalah untuk mengetahui ada tidaknya pengaruh dari variabel dependen transparansi $\left(\mathrm{X}_{1}\right)$, akuntabilitas $\left(\mathrm{X}_{2}\right)$, dan pemanfaatan SIAKD $\left(\mathrm{X}_{3}\right)$ secara bersama-sama (simultan) terhadap variabel dependen pengelolaan APBD (Y).

Tabel 4

Ringkasan Hasil Analisis Regresi Berganda Hipotesis 4

\begin{tabular}{|c|c|c|c|}
\hline Dependent Variable: Pengelolaan APBD (Y) & Big \\
\hline Variabel Independen & B & T & Sig \\
\hline
\end{tabular}




\begin{tabular}{|c|c|c|c|c|c|c|c|}
\hline \multicolumn{4}{|c|}{ (Constant) } & & 9.519 & 2.449 & 0.000 \\
\hline \multicolumn{4}{|c|}{ Transparansi $\left(\mathrm{X}_{1}\right)$} & & 0.222 & 1.798 & 0.001 \\
\hline \multicolumn{4}{|c|}{ Akuntabilitas $\left(\mathrm{X}_{2}\right)$} & & 0.141 & 1.174 & 0.003 \\
\hline \multicolumn{4}{|c|}{ Pemanfaatan SIAKD $\left(\mathrm{X}_{3}\right)$} & & 0.700 & 5.532 & 0.000 \\
\hline $\mathrm{R}^{2}$ & $=$ & 0.450 & \multicolumn{5}{|c|}{ Adjusted $\mathrm{R}^{2}=0.430$} \\
\hline $\mathrm{R}$ & $=$ & 0.671 & \multicolumn{2}{|c|}{ Sig $=$} & \multicolumn{3}{|l|}{0.000} \\
\hline F hitung & $=$ & 22.115 & F tabel & $=$ & 2.72 & & \\
\hline \multicolumn{8}{|c|}{ Keterangan: *Signifikan pada taraf kepercayaan $95 \%$} \\
\hline \multicolumn{4}{|r|}{$\mathrm{Y}=a+b 1 \mathrm{X} 1+\mathrm{b} 2 \mathrm{X} 2+\mathrm{b}$} & \multicolumn{4}{|c|}{$\mathrm{Y}=a+b 1 \mathrm{X} 1+\mathrm{b} 2 \mathrm{X} 2+\mathrm{b} 3 \mathrm{X} 3+\mathrm{e}$} \\
\hline \multicolumn{2}{|c|}{ Regresinya } & $=$ & \multicolumn{5}{|c|}{$\mathrm{Y}=9,519+0,222 \mathrm{X}_{1}+0.141+0,700+\mathrm{e}$} \\
\hline
\end{tabular}

Nilai $\mathrm{R}=0,671$ yang berarti terjadi hubungan yang kuat antara variabel-variabel independen dengan variabel dependen sebesar $67,1 \%$. Nilai adjusted $\mathrm{R}^{2}$ (koefisien determinasi) sebesar 0,430 , hal ini berarti $43 \%$, pengelolaan APBD dapat dijelaskan oleh variabel-variabel independen transparansi, akuntabilitas, dan pemanfaatan SIAKD. Sedangkan sisanya dijelaskan oleh sebab - sebab yang lain diluar model yang mempengaruhi pengelolaan APBD.

Untuk mengukur apakah variabel independen berpengaruh secara bersama-sama (simultan) terhadap variabel dependen dapat dilihat dari table 4.20 hasil uji $\mathrm{F}$ berikut:

Tabel 5

Uji Simultan (Uji F)

ANOVA $^{\text {b }}$

\begin{tabular}{|ll|r|r|r|r|r|}
\hline \multicolumn{1}{|l|}{ Model } & Sum of Squares & Df & Mean Square & F & Sig. \\
\hline 1 & Regression & 626.585 & 3 & 208.862 & 22.115 & $.000^{\mathrm{a}}$ \\
& Residual & 764.992 & 81 & 9.444 & & \\
Total & 1391.576 & 84 & & & \\
\hline
\end{tabular}

a. Predictors: (Constant), Pemanfaatan SIAKD, Transparansi, Akuntabilitas

b. Dependent Variable: Pengelolaan APBD

Sumber : data primer diolah (2015)

Dari tabel uji $\mathrm{F}$ dan tabel ringkasan analisis hasil analisis regresi berganda menunjukkan nilai $\mathrm{F}_{\text {hitung }}$ sebesar 22,115 $>\mathrm{F}_{\text {tabel }} 2,72$ dengan nilai probabilita sig $=0,000<\alpha 0,05$. Maka dapat disimpulkan bahwa $\mathrm{H}_{\mathrm{a} 1}$ diterima dan $\mathrm{H}_{01}$ ditolak.

\subsection{Pembahasan}

Hasil pengujian dari hipotesis pertama, dengan persamaan regresi menunjukkan angka positif, yang berarti bahwa dengan semakin meningkatnya transparansi, maka pengelolaan APBD juga akan semakin baik. Artinya apabila pejabat yang melaksakan pengelolaan APBD pada seluruh Dinas Pemerintah Kota Padang melakukan transparansi, maka pengelolaan APBD telah mengacu kepada pengelolaan keuangan daerah yang menerapkan prinsip value for money. Sejalan dengan teori yang pernah dinyatakan oleh Sumarsono (2003) bahwa, pengelolaan APBD yang mengarah pada transparansi akan meningkatkan ekonomi, efisiensi dan efektivitas. Maka semakin baik transparansi, semakin baik pula pengelolaan APBD pada suatu daerah. Sesuai dengan Permendagri No. 13 tahun 2006 yang sudah diperbaharui dengan Permendagri No. 21 tahun 2011. Tentang pedoman pengelolaan keuangan daerah, menyatakan bahwa pengelolaan keuangan daerah harus dilakukan secara ekonomi, efisien dan efektif dengan prinsip transparan, yaitu keterbukaan yang 
memungkinkan masyarakat untuk mengetahui dan mendapatkan akses informasi seluas-luasnya tentang pengelolaan keuangan daerah.

Hasil pengujian hipotesis kedua, dengan persamaan regresi menunjukkan angka positif, yang berarti bahwa dengan semakin meningkatnya akuntabilitas, maka pengelolaan APBD juga akan semakin baik. Artinya apabila semakin akuntabelnya pejabat pengelola dalam melaksanakan pengelolaan APBD pada seluruh Dinas Pemerintah Kota Padang, maka pengelolaan APBD telah mengacu kepada pengelolaan keuangan daerah yang menerapkan prinsip value for money. Sesuai dengan teori keagenan pada sektor publik bahwa, fungsi pemerintah sebagai pemegang amanah (agent) yang berkewajiban untuk memberikan pertanggungjawaban, menyajikan, melaporkan dan mengungkapkan segala aktivitasnya yang menjadi tanggungjawabnya kepada pihak pemberi amanah (principal) dalam hal ini masyarakat (Halim, 2006). Sesuai dengan Permendagri No. 21 tahun 2011 menyatakan bahwa pengelolaan keuangan daerah harus dilakukan secara ekonomi, efisien dan efektif dengan prinsip akuntabilitas, yang merupakan perwujudan kewajiban seseorang untuk mempertanggungjawabkan pengelolaan dan pengendalian sumber daya dan pelaksanaan kebijakan pelaksanaan kebijakan yang dipercayakan kepadanya dalam rangka pencapaian tujuan yang ditetapkan.

Hasil pengujian hipotesis ketiga, dengan persamaan regresi menunjukkan angka positif, yang berarti bahwa dengan semakin meningkatnya pemanfaatan SIAKD, maka pengelolaan APBD juga akan semakin baik. Artinya apabila pejabat pengelolaan keuangan daerah memanfaatkan SIAKD secara menyeluruh pada setiap proses dalam pelaksanaan pengelolaan APBD, maka pengelolaan APBD akan semakin ekonomi, efisien dan efektif sesuai dengan prinsip value for money. Sesuai dengan Peraturan Pemerintah No. 65 Tahun 2010 tentang Sistem Informasi Keuangan Daerah bahwa untuk menindaklanjuti terselenggaranya proses pembangunan yang sejalan dengan prinsip tata kelola pemerintah yang baik (good governance), Pemerintah Pusat dan Pemerintah Daerah berkewajiban untuk mengembangkan dan memanfaatkan kemajuan teknologi informasi untuk meningkatkan kemampuan pengelolaan keuangan, dan menyalurkan informasi keuangan kepada publik.

Hasil pengujian hipotesis keempat, dengan persamaan regresi menunjukkan angka positif, artinya apabila pengelolaan APBD dilakukan secara transparan, akuntabel, dan memanfaatkan SIAKD maka pengelolaan APBD yang dilakukan akan mengacu pada prinsip value for money, pengelolaan yang ekonomi, efesien dan efektif, sehingga pemanfaatan atau alokasi APBD yang tidak boros atau hemat, merata dan adil, dan sesuai dengan kebutuhan masyarakat semakin dapat dicapai.

Dengan adanya pelaksanaan trasparansi, akuntabilitas, dan pemanfaatan SIAKD dalam pengelolaan APBD, diharapkan setiap pejabat yang bersangkutan bisa lebih hati-hati, cepat dan akurat dalam menjalankan hak dan kewajibannya sebagai penerima amanah (agent) kepada pemberi amanah yaitu masyarakat (principal). Karena pengelolaan keuangan daerah merupakan salah satu aspek dari pemerintah daerah yang harus diatur secara hati-hati, yang pengaruhnya sangat sangat besar terhadap nasib suatu daerah.

\section{PENUTUP}

Berdasarkan analisis yang dilakukan sebelumnya, maka ada beberapa hal yang dapat disimpulkan dalam penelitian ini. Pertama, Transparansi, akuntabilitas dan pemanfaatan SIAKD secara parsial melalui uji $t$ berpengaruh signifikan terhadap pengelolaan APBD sehingga hipotesis diterima. Kedua, secara bersama-sama (simultan) melalui uji F, transparansi, akuntabilitas dan pemanfaatan SIAKD berpengaruh terhadap pengelolaan APBD sehingga hipotesis diterima. Untuk bisa lebih meningkatkan pengelolaan keuangan daerah terutama dalam pengelolaan anggaran pada SKPD, yang mengacu pada prinsip value for money dan mendukung tercapainya tata kelola pemerintah yang baik, maka implikasi dari temuan penelitian ini yaitu menunjukkan bahwa korelasi antara transparansi dan akuntabilitas dengan pengelolaan APBD memiliki hubungan yang sedang dengan pengelolaan APBD, hal ini berarti bahwa transparansi dan akuntabilitas sudah diterapkan dengan baik pada SKPD Dinas Pemerintah Kota Padang, akan tetapi butuh penerapan secara maksimal dan menyeluruh lagi. Agar tercipta hubungan yang kuat antara variable tersebut. Karena transparansi 
dan akuntabilitas merupakan dua komponen utama untuk terciptanya tatakelola yang baik. Maka diharapkan pada Pemerintah Kota Padang khususnya pejabat pengelolaa APBD pada SKPD untuk lebih meningkatkan transparansi dan lebih akuntabel lagi dalam pengelolaan anggaran.

Kesimpulan pada penelitian ini harus dilihat dari beberapa keterbatasan yang ada dalam penelitian ini, antara lain: (1) Data penelitian ini berasal dari persepsi responden yang disampaikan secara tertulis melalui instrumen kuisioner, mungkin akan mempengaruhi validitas hasil. Karena persepsi responden yang disampaikan belum tentu mencerminkan keadaan sesungguhnya. Kemudian kuisioner yang disebar hanya pada SKPD Dinas tanpa mengikutkan SKPD di luar dinas. (2) Dalam penelitian ini, peneliti hanya menggunakan 4 variabel independen yaitu transparansi, akuntabilitas, dan pemanfaatan SIAKD. Dan 1 (satu) variabel dependen yaitu pengelolaan APBD sehingga penelitian ini sebatas variabel-variabel tersebut, masih banyak kemungkinan variabel-variabel lain yang bisa digali yang berkemungkinan memiliki hubungan yang kuat dengan pengelolaan APBD.

Penelitian ini diharapkan dapat memberikan ide untuk pengembangan penelitian selanjutnya. Berdasarkan keterbatasan yang ada, penelitian selanjutnya diharapkan dapat mempertimbangakan beberapa hal. Pertama, bagi peneliti selanjutnya untuk menambah responden, tidak hanya pada SKPD Dinas tetapi seluruh SKPD yang ada pada Pemerintah kota Padang. Selain menambah responden juga menambahkan beberapa elemen lain lagi dari good governance untuk penambahan variabel untuk penelitian terkait pengelolaan APBD ini. Kemudian untuk lebih akuratnya penelitian selain menggunakan instrument kuisioner hendaknya juga menggunakan wawancara. Sehingga dapat mempertajam penelitian selanjutnya yang nantinya dapat berguna bagi pihak-pihak yang membutuhkan. Kedua, diharapkan bagi peneliti selanjutnya yang tertarik melanjutkan penelitian ini, untuk menambah variable penelitian, tidak hanya terbatas pada transparansi, akuntabilitas, dan pemanfaatan SIAKD. Karena masih banyak kemungkinan variable-variabel lain yang bisa digali dan memiliki hubungan yang kuat dengan pengelolaan anggaran.

\section{DAFTAR PUSTAKA}

Abu Bakar Nur Barizah, Saleh Zakia, \& Sani Mohammad Muslim Har. 2011. Enchanging Malaysian Public Sector Transparency and Accountability: Lesson and Issues. Malaysia. Journal. International Islamic University Malaysia.

Asian Development Bank. 1999. Good Governance and Anticorruption: The Road Forward For Indonesia: ADB Publication.

Ahmad, Yani.2008. Hubungan Keuangan Antara Pemerintah Pusat dan Daerah Di Indonesia, Jakarta: Rajawali Pers.

Anthony, Robert N. dan Vijay Govindarajan. 2005. Management Control Systems. Salemba Empat: Jakarta

Arief, Wibowo. 2008. Kajian Tentang Perilaku Pengguna Sistem Informasi Dengan Pendekatan Technology Acceptance Model (TAM). Jakarta

Bappeda.padangkota.go.id : Visi Misi Kota Padang.

Bastian, Indra. 2016. Akuntansi Sektor Publik, Suatu Pengantar, Jakarta : Penerbit Erlangga

Darise, Nurlan. 2007. Pengelolaan Keuangan Daerah. Indeks, Jakarta

Diani, Irma Dian, 2014. Pengaruh Pemahaman Akuntansi, Pemanfaatan Sistem Informasi Akuntansi Keuangan Daerah dan Peran Internal Audit Terhadap Kualitas Laporan Keuangan Pemerintah Daerah. Skripsi. UNP. Padang.

Fozzard, Adrian. 2001. The basic budgeting problem: Approaches to resource allocation in the public sector and their implications for pro-poor budgeting. Center for Aid and Public Expenditure, Overseas Development Institute (ODI). Working paper 147.

Ghozali, Imam. 2007. Aplikasi Analisis Multivariate dengan Program SPSS. Semarang: Universitas Diponegoro.

Grace, Ofoegbu N. 2014. New Public Management and Accrual Accounting Basis for Transparency and Accountability in the Nigerian Public Sector. ISSN Journal. 
Hadryanto, Pahala, 2012. Pengaruh Akuntabilitas dan Transparansi Terhadap Pengelolaan Anggaran di Universitas Bina Nusantara. Universitas Bina Nusantara.

Halim, Abdul. 2004. Manajemen Keuangan Daerah. Yogyakarta. Penerbit Bunga Rampai.

Halim, Abdul. 2002. Akuntansi Keuangan Daerah. Jakarta. Penerbit Salemba Empat.

Halim dan Syukriy Abdullah. 2006. Hubungan dan masalah keagenan di pemerintahan daerah: Sebuah peluang penelitian anggaran dan akuntansi. Jurnal Akuntansi Pemerintah 2(1): 53-64.

Hartono, Jogiyanto, Sistem Informasi Keperilakuan. Andy Offset, 2007.

http://databank.worldbank.org/ddp/home.do?Step=3\&id=4 diakses 28 Maret 2015.

http://www.bpk.go.id/news/bpk-akses-on-line, diakses 28 April 2015

http://www.padang.go.id/index.php/skpd, diakses 28 Apil 2015

http://software-indo.com/sistem-informasi-akuntansi-keuangan-daerah-siakd, diakses 18 Agustus 2015

Latifah, Nurul P. 2010. Adakah Perilaku Oportunistik dalam Aplikasi Agency Theory diSektor Publik. Jurnal Fokus Ekonomi Vol. 5 No. 2 Desember 2010. Semarang.

Lowry, Robert \& James. 2010. Transparency and Accountability : Empirical Results for US States. Article. Scholarship at Harvard.

Mardiasmo, 2004. Otonomi dan Manajemen Keuangan Daerah: good governance democration local government financial management transparancy public policy , Andi, Yogyakarta;

Mardiasmo. 2009. Akuntansi Sektor Publik. Yogyakarta. Penerbit Andi

Mardiasmo. 2006. Perwujudan Transparansi dan Akuntabilitas Publik Melalui Akuntansi Sektor Publik: Suatu Sarana Good Governace. Jurnal Akuntansi Pemerintahan Vol. 2, No.1, Mei 2006.

MD Ihyaul Ulum, 2009. Audit Sektor Publik. Bumi Aksara, Jakarta.

Mulyono, Imam. 2008. Uji Empiris Model Kesuksesan Sistem Informasi Keuangan Daerah (Sikd) dalam Rangka Peningkatan Transparasi dan Akuntabilitas Keuangan Daerah. Simposium Nasional Akuntansi XII. Pekan Baru

Noordiawan, Putra, Rahmawati, 2007. Akuntansi Pemerintahan. Salemba Empat, Jakarta.

Petrie, Murray. 2002. A framework for public sector performance contracting. OECD Journal on Budgeting: 117-153.

Pujiswara, Herawati, \& Sinarwati, 2014. Pengaruh Pemanfaatan SIAKD dan Pengawasan Keuangan Daerah Terhadap Nilai Informasi Pelaporan keuangan dan Akuntabilitas Pemerintah Daerah Pada SKPD Kabupaten Klungkung. Ejournal Akuntansi. Universitas Pendidikan Ganesha. Singaraja

Rahmawati Novia, Rifa Dandes, \& Handri Purnama Yuia, 2014. Pengaruh Penyajian Laporan Posisi Keuangan, Aksebilitas Laporan Keuangan dan Sistem Akuntansi Keuangan Daerah Terhadap Transparansi dan Akuntabilitas Pengelolaan Keuangan SKPD Pemerintah Kota Padang. Jurnal Akuntansi. Universitas Bung Hatta. Padang.

Republik Indonesia, Peraturan Pemerintah Nomor 41 Tahun 2007 Tentang Organisasi Perangkat Daerah.

Republik Indonesia, Peraturan Pemerintah Republik Indonesia No. 58 Tahun 2005 Tentang Pengelolaan Keuangan Daerah

Republik Indonesia, Undang-Undang No. 32 Tahun 2004 Tentang Pemerintahan Daerah.

Republik Indonesia, Undang-Undang No.17 Tahun 2003 Tentang Keuangan Negara.

Republik Indonesia, Peraturan Menteri Dalam Negeri No. 13 tahun 2006. Tentang Pedoman Pengelolaan Keuangan Daerah.

Republik Indonesia, Peraturan Menteri Dalam Negeri No. 21 tahun 2011. Tentang Pedoman Pengelolaan Keuangan Daerah.

Republik Indonesia, Peraturan Menteri Dalam Negeri No. 59 Tahun 2007. Tentang Pengelolaan Keuangan Daerah.

Republik Indonesia, Peraturan Pemerintah Nomor 65 Tahun 2010, tentang Sistem Informasi Keuangan Daerah.

Renyowijoyo Muindro, 2008. Akuntansi Sektor Publik Organisasi Non Laba, Mitra Wacana Media Jakarta.

Ridhawati, 2014. Pengaruh Kapasitas Sumber Daya Manusia dan Pemanfaatan Teknologi Informasi Terhadap Keandalan dan Ketepatan Waktu Laporan Keuangan Pemerintah Daerah Kabupaten/Kota di Provinsi Sumatera Barat. Tesis. Universitas Andalas Padang.

Sagara, Yusar, 2015. The Effect of Implementation Accounting Information System and Competence of Human Resources on the Quality of Financial Reporting. Research Journal of Finance and Accounting. ISSN 2222-1697 (Paper) ISSN 2222-2847 (Online. The Student of Accounting Doctoral Program Faculty of Economic and Business Padjajaran University-Indonesia.

Sekaran, Uma. 2006. Research Method for Business. Jakarta. Salemba Empat. 
Siregar, Liper, 2011. Pengaruh Akuntabilitas Publik, Transparansi Publik, dan Pengawasan Terhadap Pengelolaan APBD pada Pemerintah Kota Pematang Siantar. Tesis, Universitas Sumatera Utara, Medan.

Siswanto, Ely, 2013. Good University Income Generating Governance in Indonesia : Agency Theory Perspective. International Journal of Learning \& Development. (ISSN) Vol. 3 No.1.

Sukesti, Fatmasari \& Alfasadun. 2011. Transparansi APBD sebagai Sarana Akuntabilitas Publik. Jurnal Akuntansi.

Shende, S. and T. Bennett. 2004. Transparency and Accountability in Public Financial Administration. Concept Paper, United Nations

Sugiyono. 2013. Metode Penelitian Bisnis : Pendekatan Kuantitatif Kualitatif dan R\&D. Bandung. Alfabeta.

Sugiyono, 2012. Metode Penelitian Kombinasi (Mixed method). Alfabeta.Bandung.

Sugiyono, 2010. Statistika Untuk Penelitian, Alfabeta CV, Bandung

Sumarsono, Hadi, 2009. Analisis kemandirian Otonomi Daerah. Jurnal Akuntansi Pemerintah Vol.1 No.1, 2009

Suparno. 2012. Pengaruh Akuntabilitas Keuangan Daerah, Value For Money, dan Transparansi Terhadap Penglolaan Keuangan Daerah Pada Pemerintah Kota Dumai. Tesis. USU

Syakhroza, Akhmad. Reformasi Profesi Akuntansi Sektor Publik dan Good Government Governance, "Usahawan". 2003.

Umar Husein, 2003. Riset Akuntansi Terapan, Galia Indenesia, Jakarta.

Von Hagen, Jurgen. 2002. Fiscal rules, fiscal institutions, and fiscal performance. The Economic and Social review 33(3): 263-284.

World Bank (1992) Governance and Development. Washington: The World Bank.

www.koran.padek.co/read/, diakses 28 April 2015

Yuliani, Safrida, Nadirsyah, dan Bakar Usman. 2010. Pengaruh Pemahaman Akuntansi, Pemanfaatan Sistem Informasi Akuntansi Keuangan Daerah dan Peran Internal Audit Terhadap Kualitas Laporan Keuangan Pemerintah Daerah Kota Banda Aceh. Jurnal Telaah dan Riset Akuntansi Pasca Sarjana Universitas Syiah Kuala. Aceh. 